\begin{tabular}{|c|c|}
\hline 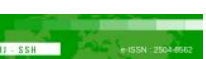 & Malaysian Journal of Social Sciences and Humanities (MJSSH) \\
\hline Malaysian Journal of & Volume 6, Issue 8, August 2021 \\
\hline (MJ-SSH) & e-ISSN : 2504-8562 \\
\hline & $\begin{array}{l}\text { Journal home page: } \\
\text { www.msocialsciences.com }\end{array}$ \\
\hline
\end{tabular}

\title{
Hubungan Pengurusan Disiplin Sekolah dan Kualiti Kehidupan Murid di Semenanjung Utara Malaysia
}

\author{
Sire Etum ${ }^{1}$, Al-Amin Mydin'1, Abdul Ghani Kanesan Abdullah' ${ }^{1}$ \\ ${ }_{1}^{1}$ Pusat Pengajian Ilmu Pendidikan, Universiti Sains Malaysia (USM) \\ Correspondence: Sire Etum (drsireetum@student.usm.my)
}

\begin{abstract}
Abstrak
Pengurusan disiplin sekolah merupakan aspek yang penting dalam memastikan kehidupan murid lebih berkualiti tinggi. Setiap sekolah mempunyai sistem peraturan masing-masing yang diwujudkan bagi membendung masalah disiplin para murid. Sungguhpun begitu, murid sering mempamerkan tingkah laku yang negatif walaupun peraturan sudah ditetapkan. Ini menunjukkan bahawa sistem pengurusan disiplin sekolah masih lagi tidak diber penekanan dalam memastikan kehidupan murid lebih berkualiti. Justeru, kajian ini dijalankan bagi mengenal pasti hubungan pengurusan disiplin sekolah dan kualiti kehidupan murid sekolah menengah di Semenanjung Utara Malaysia. Seramai 539 orang murid tingkatan empat terlibat dalam kajian ini yang dipilih menggunakan pensampelan pelbagai peringkat. Instrumen pengurusan disiplin sekolah mengandungi 18 item yang diadaptasikan daripada Kalaichalvi (2012). Di samping itu, instrumen kualiti kehidupan murid mengandungi sepuluh item dan diolah daripada Stegar et al. (2006). Dapatan menunjukkan bahawa tahap pengurusan disiplin sekolah adalah tinggi $(\mathrm{M}=4.09)$, manakala kualiti kehidupan murid turut berada pada tahap yang tinggi $(M=3,94)$. Keputusan kajian turut mendapati bahawa terhadap hubungan positif yang sederhana di antara kedua-dua pemboleh ubah dengan nilai korelasi, $r=0.45$. Secara keseluruhannya, pengurusan disiplin sekolah mempunyai peranan yang besar dalam membentuk kualiti kehidupan seseorang murid. Mereka akan lebih patuh dan mempamerkan tingkah laku yang unggul sekiranya tahap pengurusan disiplin di sesuatu sekolah ditadbir dengan baik.
\end{abstract}

Kata kunci: pengurusan disiplin sekolah, kualiti kehidupan murid, tingkah laku murid

\section{The Relationship Between School Discipline Management and The Quality of Student Life in The Northern Peninsular of Malaysia}

\begin{abstract}
The management of school discipline is a critical aspect in ensuring a higher quality of student life. Each school has its system of rules created to curb students' disciplinary problems. Even so, students often exhibit negative behaviours even when rules are already in place. This phenomenon shows that each school's discipline management system is looser in ensuring a better quality of life. Thus, this study was conducted to identify the relationship between school discipline management and the quality of life of secondary school students in Northern Peninsula Malaysia. A total of 539 form four students were involved in this study who were selected using multi-level sampling. The school discipline management instrument contains 18 items adapted from Kalaichalvi (2012). In addition, the student quality of life instrument contained ten items and was elaborated from Stegar et al. (2006). Findings show that the level
\end{abstract}


of school discipline management is high $(\mathrm{M}=4.09)$, while students' quality of life is also at a high level $(\mathrm{M}=3.94)$. The study results also found that against a moderate positive relationship between the two variables with a correlation value, $r=0.45$. Overall, school discipline management has a massive role in shaping a student's quality of life. They will be more compliant and exhibit exemplary behaviours if disciplinary management in a school is well-governed.

Keywords: management of school discipline, quality of student life, student behavior

\section{Pengenalan}

Disiplin murid merupakan peraturan yang perlu dipatuhi oleh murid di sekolah (Lam, 2013). Hal ini bertujuan bagi melatih murid untuk sentiasa berkelakuan baik sewaktu berada di kawasan sekolah. Lantaran itu, pengurusan disiplin sekolah adalah faktor utama dalam memastikan murid sentiasa beretika tinggi dan menuruti arahan-arahan yang ditetapkan. Sistem ini diperuntukkan bagi memastikan persekitaran pembelajaran di sekolah adalah lebih kondusif. Secara logiknya, peraturan yang dibina bukan untuk membebankan murid, bahkan untuk memastikan objektif dan visi sekolah yang dirancang dapat dicapai dengan jayanya. Pihak pentadbiran sekolah harus memastikan bahawa pengurusan disiplin ini dilaksanakan dengan cemerlang bagi menangani permasalahan tingkah laku negatif murid yang semakin membimbangkan pada masa kini (Omemu, 2017).

Keberkesanan pengurusan disiplin sekolah dapat dipertontonkan melalui pengurangan kadar kes-kes yang berlaku di persekitaran sekolah. Sekiranya hal ini berterusan, maka pembangunan sosial murid dapat dibentuk dengan lebih baik (Raskaukas \& Modell, 2011). Sebaliknya, kegagalan menguruskan sistem disiplin sekolah akan mengganggu suasana pembelajaran sedia ada. Sikap murid yang negatif biasanya akan mempamerkan tingkah laku seperti ponteng kelas, merokok, buli, vandalisme dan lainlain lagi. Pihak sekolah tidak boleh membiarkan hal ini terus bermaharajalela dalam kalangan murid kerana lambat laun akan mempengaruhi tingkah laku murid yang lain. Oleh itu, Syahril dan Hadiyanto (2018) menegaskan bahawa kecemerlangan pengurusan disiplin sekolah terbentuk melalui kecekapan pentadbiran sekolah yang sama-sama sentiasa cakna bagi mengatasi setiap permasalahan berpunca dari tingkah laku negatif murid dan perspektif negatif penilaian murid terhadap pengurusan disiplin sekolah.

Pengurusan disiplin sekolah biasanya ditadbir selia oleh seorang penolong kanan, guru disiplin dan beberapa ahli jawatankuasa disiplin sekolah. Jawatankuasa ini berfungsi untuk memastikan sistem peraturan sekolah dapat membentuk murid supaya mempunyai kualiti kehidupan yang lebih baik ketika mengharungi sesi persekolahan. Dalam situasi ini, Phuntsho (2021) mendapati pengurusan disiplin sekolah mestilah sentiasa adil dan saksama bagi ketika sesuatu peraturan dikuatkuasakan. Ini adalah bagi mengelakkan murid berasa tertekan, seterusnya mengundang lebih banyak lagi kesan sampingan yang lain. Dengan itu, guru disiplin terutamanya harus memastikan konsep pengurusan disiplin sekolah dijalankan mengikut undang-undang yang telah ditetapkan. Setiap hukuman harus diberikan sebab yang munasabah dan tindakan yang diambil itu adalah berdasarkan kepada konsep pelanggaran disiplin melalui bukti-bukti yang sangat jelas (Lam, 2013).

Oleh itu, pengurusan disiplin sekolah harus ditadbir secara cekap bagi memastikan kualiti kehidupan murid di sekolah tidak terjejas. Hal ini dipersetujui oleh Lawa, Wiyono dan Supriyanto (2019) di mana pihak sekolah harus menyusun atur sistem pengurusan disiplin supaya lebih sistematik. Seandainya tidak dikuatkuasakan sesuatu peraturan dengan terancang, hal ini mungkin akan mengakibatkan kesan yang buruk kepada kualiti kehidupan murid. Fenomena mudah ini boleh berlaku apabila seseorang guru disiplin bertindak secara melulu dengan menghukum murid tanpa mengikut lunas-lunas peraturan yang ditetapkan oleh pihak sekolah (Mancini, 2017). Kajian-kajian terdahulu telah membuktikan bahawa pengurusan disiplin sekolah yang cemerlang mencerminkan keberkesanan guru-guru jawatankuasa disiplin melaksanakan amanah dengan baik mengikut peraturan sedia ada sekaligus mewujudkan perspektif positif penilaian murid terhadap pengurusan disiplin sekolah (Moloi, 2003; Atunde \& Aliyu, 
2019). Oleh sebab itu, murid tidak akan rasa tertekan, bahkan mampu mengikuti setiap peraturan sekolah dengan baik seandainya pengurusan disiplin sekolah diselia dengan cemerlang.

\section{Sorotan Literatur}

Aturan kehidupan yang dipenuhi dengan kemudahan teknologi pada masa kini sedikit sebanyak telah melengkapi keperluan dan kehendak murid. Kepuasan murid digambarkan melalui keseronokan dan kegirangan menggunakan teknologi yang dianggap sebagai suatu kewajipan bagi memenuhi kualiti kehidupan mereka ketika ini. Namun begitu, kualiti kehidupan murid di alam persekolahan sangat berbeza dengan realiti sebenar yang berlaku di dunia luar. Hal ini kerana sekolah dilengkapi dengan peraturan dan arahan-arahan yang perlu murid ikuti demi memastikan sistem pendidikan dapat diatur dengan lebih sempurna. Secara tidak langsung, sistem pengurusan sekolah memainkan peranan yang sangat besar bagi memastikan para murid berasa selamat, tidak terbeban dan kurang kebimbangan seandainya mereka telah melakukan sebarang kesilapan (Gage, Larson, Sugai, \& Chafouleas, 2016). Oleh sebab itu, Lam Lee Mein (2013) mencadangkan tiga aspek yang patut diikuti bagi memastikan keberkesanan pengurusan disiplin sekolah secara holistik. Tiga aspek berkenaan adalah seperti berikut:

i. Menyediakan asas-asas kawalan tatatertib yang bersesuaian bagi menentukan sesuatu kesalahan atau pelanggaran disiplin.

ii. Melaksanakan proses tatatertib dengan adil dan saksama.

iii. Mengenakan hukuman tatatertib yang setimpal dengan kesalahan yang dilaksanakan.

Kajian sebelum ini oleh Anyon et al. (2016) menunjukkan kualiti kehidupan murid di sekolah adalah berpunca daripada sistem pengurusan disiplin yang sangat teratur. Selain itu, Mohd Ismail Othman (2006) turut mengakui bahawa keberkesanan pengurusan disiplin sekolah akan menyebabkan murid lebih bersedia untuk mengekalkan tingkah laku mereka yang positif sehingga dapat menerima setiap peraturan yang dikuatkuasakan. Justeru, majoriti sekolah telah menggubal peraturan sekolah dengan mengambil kira konsep perundangan dan pekeliling sedia ada dari masa ke semasa. Dalam hal ini, pentadbir sekolah mempunyai kuasa mutlak untuk mengagihkan dan menurunkan kuasa pelaksanaan kawalan tatatertib kepada jawatankuasa-jawatankuasa yang dibentuk di sekolah (Quinn, 2017). Jawatankuasa seperti badan disiplin sekolah dan lembaga pengawas diperuntukkan kuasa untuk melaksanakan tindakan yang sewajarnya seperti menyiasat kes-kes salah laku murid, membicarakan dengan adil dan saksama serta mengenakan hukuman yang setimpal dengan kesalahan yang dilakukan.

Sebaiknya, sistem pengurusan disiplin harus mengikuti terma-terma yang ditetapkan oleh Kementerian Pendidikan Malaysia (KPM) dari masa ke semasa (Mohd Ismail Othman, 2006). Sebagai contoh, Surat Pekeliling Bil. 9/1975 (Perkara 4) telah menjelaskan bahawa pihak sekolah seharusnya mempunyai peraturan-peraturan khas yang digubal mengikut kesesuaian masing-masing dan ditetapkan secara bertulis. Perkara ini selari dengan cadangan Gregory, Clawson, Davis dan Gerewitz (2016), di mana sesuatu peraturan yang dibentuk itu mempunyai maksud yang jelas dan mudah difahami oleh semua guru serta murid. Dengan itu, secara tidak langsung warga sekolah dapat mengetahui apakah yang perlu dilaksanakan sekiranya sesuatu permasalahan disiplin murid timbul. Proses ini sebenarnya telah menghasilkan kualiti kehidupan murid yang lebih baik apabila sekolah begitu cakna dengan permasalahan disiplin dan mengambil tindakan yang betul berdasarkan kepada apa yang tercatat dalam undang-undang sedia ada.

\section{Pengurusan Disiplin Sekolah}

Pengurusan disiplin sekolah adalah proses perancangan, pengorganisasian, pengarahan dan pengawalan melibatkan peraturan serta arahan-arahan yang dibentuk bagi memastikan murid sentiasa berada pada situasi yang baik (Mohd Faizal et al., 2014). Keberkesanan pengurusan disiplin menggalakkan murid bertindak laku yang lebih positif pada setiap masa ketika berada di persekitaran sekolah. Oleh itu, sistem pengurusan disiplin yang cemerlang mampu mempengaruhi kualiti kehidupan murid secara holistik (Lam, 2013). Murid yang mempunyai kualiti kehidupan yang baik lebih mudah untuk menerima dan 
mengadaptasikan kaedah penilaian peraturan sekolah yang dibentuk berdasarkan undang-undang semasa.

Guru disiplin sekolah memainkan peranan yang sangat penting untuk memastikan sistem pengurusan disiplin sekolah sentiasa dikelola dengan baik. Mereka bertindak sebagai pengantara bagi membantu pihak sekolah dalam membentuk sistem pengurusan disiplin yang efektif melalui penetapan peraturanperaturan sekolah yang telah ditentukan. Sekiranya sistem pengurusan ditadbir dengan baik, maka hal ini akan memberi kesan kepada pembinaan tingkah laku murid yang lebih positif (Offem, Arop, \& Owan, 2019). Guru boleh mengetahui sama ada sesuatu peraturan sekolah tersebut diterima atau sebaliknya adalah melalui konsep penilaian terhadap murid. Hal ini boleh dikesan melalui pendapat yang dikemukakan oleh murid ataupun pemerhatian terhadap tingkah laku mereka seharian. Realitinya, keberkesanan sistem pengurusan disiplin sekolah dapat diperhatikan melalui tingkah laku positif murid yang bertindak balas seperti tidak melanggar peraturan sekolah dan menerima setiap peraturan tersebut dengan hati terbuka (Jinot, 2018).

Sungguhpun begitu, sistem pengurusan disiplin sekolah gagal mencapai matlamat seandainya masih terdapat murid melakukan kesalahan yang sama walaupun telah dikuatkuasakan peraturan tersebut. Hal ini secara tidak langsung akan menyebabkan kualiti kehidupan murid di sekolah tidak mencapai tahap yang dikehendaki. Menurut Gage et al. (2016) masalah disiplin kerap kali berlaku secara berulang disebabkan oleh kepuasan murid untuk menikmati kualiti kehidupan adalah sangat rendah. Kesannya, pengawalan disiplin dalam kalangan murid sekolah akan terus merosot dan gagal mencapai kualiti kehidupan yang diidamkan (Nyaga, 2018). Justeru, pengurusan disiplin sekolah harus ditadbir dengan lebih sempurna bagi memastikan fungsinya lebih terarah dalam menangani setiap permasalahan salah laku murid di persekitaran sekolah.

\section{Kualiti Kehidupan Murid}

Kualiti kehidupan murid adalah merupakan tingkah laku seseorang murid bagi mencapai sesuatu yang lebih bermakna dalam hidup dengan mementingkan kepuasan diri secara lebih sihat (Steger, Frazier, Shigehiro, \& Oishi, 2006). Berdasarkan kajian Mitreva, Risteski dan Tushi (2020), seseorang murid yang mencapai kehidupan yang berkualiti akan menghadirkan kepuasan diri yang sangat tinggi sehingga mampu menjalani rutin seharian yang cemerlang. Murid akan rasa lebih bermotivasi dan berkeyakinan tinggi khususnya bagi mengharungi sesi pembelajaran dengan lebih sempurna di dalam bilik darjah. Kepuasan secara sihat turut membantu murid untuk menerima apa jua peraturan dan arahan yang ditetapkan oleh pihak sekolah. Murid akan lebih terbuka dan cuba untuk tidak melanggar setiap peraturan yang ada bagi memastikan kualiti kehidupan mereka pada tahap yang tinggi. Perkara ini menunjukkan penilaian murid terhadap peraturan sekolah secara positif.

Sebenarnya, murid lebih mudah untuk mengadaptasikan peraturan sekolah dalam diri masing-masing sekiranya mempunyai pencapaian kualiti kehidupan yang sangat baik (Mihanovic, Batinic, \& Pavicic, 2016). Murid akan cuba untuk memastikan diri mereka mengikuti setiap arahan, tidak melakukan sebarang salah laku disiplin dan memastikan hala tuju yang jelas ke arah pembentukan modal insan secara holistik. Realitinya, semua murid ke sekolah mahukan suasana yang tenteram, perasaan yang gembira, berasa sejahtera dan memastikan keselamatan diri terjaga. Hal ini hanya boleh dicapai sekiranya setiap murid memasang niat yang baik dengan cara tidak melakukan sebarang masalah disiplin ketika berada di persekitaran sekolah (Omemu, 2017). Dengan itu, kualiti murid dapat dipertingkatkan melalui sahsiah mereka yang cemerlang dan beretika dalam setiap perlakuan seharian.

\section{Metod Kajian}

\section{Reka Bentuk Kajian}

Kajian dilaksanakan menggunakan pendekatan kuantitatif. Oleh itu, borang soal selidik digunakan bagi mendapatkan data-data kajian daripada responden. Menurut Creswell (2018), kaedah kuantitatif lebih 
sesuai digunakan sekiranya melibatkan jumlah populasi yang besar. Manakala Fauzi Hussin, Jamal Ali dan Mohd Saifoul (2014) menyarankan supaya soal selidik digunakan seandainya kawasan kajian adalah terlalu luas. Hal ini adalah bagi memastikan data-data dapat dikumpulkan dengan lebih mudah. Memandangkan situasi Covid-19 yang semakin meningkat, data-data dikumpulkan menerusi borang soal selidik secara atas talian menerusi penggunaan Google Form. Dalam hal ini, pihak sekolah telah memberikan kerjasama yang sangat baik dengan memastikan murid yang terlibat mengisi borang yang disediakan secara atas talian.

\section{Populasi dan Pensampelan}

Populasi kajian ini melibatkan murid-murid tingkatan empat yang menuntut di sekolah menengah sekitar negeri Perlis, Kedah dan Pulau Pinang. Berdasarkan Sumber Maklumat KPM, jumlah murid tingkatan empat di ketiga-tiga negeri tersebut adalah seramai 10962. Oleh itu, terdapat tiga teknik pensampelan digunakan bagi mendapatkan sampel kajian sebagaimana yang dicadangkan oleh Sekaran dan Bougie (2016). Pada peringkat pertama, pensampelan berstrata digunakan untuk menyenaraikan semua sekolah harian biasa yang mempunyai murid tingkatan empat di ketiga-tiga negeri tersebut. Pada peringkat kedua, sekolah-sekolah tersebut disusun mengikut daerah masing-masing. Dalam tahap ini, pensampelan rawak bersistem digunakan di mana setiap sekolah dilabelkan dengan nombor-nombor tertentu. Sekolah yang bernombor ganjil telah dipilih sebagai sekolah kajian. Pada peringkat ketiga, teknik persampelan rawak mudah digunakan untuk memilih sampel kajian. Secara rumusannya, sebanyak 539 orang murid tingkatan empat telah dipilih hasil teknik pensampelan tersebut.

\section{Instrumen Kajian}

Instrumen pengurusan disiplin sekolah diadaptasikan daripada Kalaichalvi (2012) yang mengandungi 18 item secara keseluruhannya. Walau bagaimanapun, instrumen asal bagi pengurusan disiplin sekolah adalah dibina oleh Sigamoney pada tahun 1984. Terdapat satu dimensi sahaja dikemukakan dalam instrumen ini. Hasil ujian kebolehpercayaan mendapati nilai alpha Cronbach bagi dimensi ini adalah tinggi iaitu 0.943. Ini menunjukkan item-item yang digunakan adalah tekal dan mampu memberi makna terhadap dimensi kajian. Sementara itu, instrumen kualiti kehidupan murid pula diadaptasikan daripada Stegar et al. (2006). Instrumen asal ini dinamakan sebagai Meaning in Life Quality (MLQ). Terdapat sepuluh item yang dikemukakan dalam instrumen ini. Hasil ujian kebolehpercayaan mendapati bahawa item-item dalam instrumen ini sangat tekal. Hal ini dibuktikan melalui nilai alpha Cronbach sebanyak 0.877 .

\section{Hasil Kajian}

\section{Latar Belakang Responden}

Jadual 1 menunjukkan latar belakang responden yang terlibat dalam kajian ini. Secara keseluruhannya, seramai 539 orang murid tingkatan empat terlibat sebagai responden kajian.

Jadual 1: Latar belakang responden kajian

\begin{tabular}{llcc}
\hline Demografi & Kategori & Bilangan & Peratus (\%) \\
\hline Jantina & Lelaki & 184 & $34.1 \%$ \\
& Perempuan & 355 & $65.9 \%$ \\
\multirow{2}{*}{ Negeri } & Perlis & 109 & $20.2 \%$ \\
& Kedah & 206 & $38.2 \%$ \\
& Pulau Pinang & 224 & $41.6 \%$ \\
Lokasi Sekolah & & & \\
& Bandar & 354 & $65.7 \%$ \\
& Luar Bandar & 185 & $34.3 \%$ \\
\hline
\end{tabular}


DOI: https://doi.org/10.47405/mjssh.v6i8.925

Responden kajian terdiri daripada 188 orang murid lelaki (34.1\%), selebihnya 355 orang (65.9\%) lagi adalah murid perempuan. Lokasi kajian juga melibatkan tiga buah negeri di mana sebanyak 109 murid (20.2\%) adalah sekolah menengah di negeri Perlis, 206 orang murid (38.2\%) sekolah menengah di negeri Kedah, dan selebihnya 224 orang murid (41.6\%) sekolah menengah di negeri Pulau Pinang. Sementara itu, sebanyak 354 orang murid (657\%) murid tingkatan empat di sekolah-sekolah dalam kawasan bandar, manakala 185 orang murid (34.3\%) lagi murid di luar bandar

\section{Tahap Pemboleh Ubah Kajian}

Interpretasi data tahap pemboleh ubah kajian ini adalah berdasarkan kepada Ghazali dan Sufean (2018) iaitu 1.00-1.80 (sangat rendah), 1.81-2.60 (rendah), 2.61-3.40 (sederhana), 3.41-4.20 (tinggi) dan 4.215.00 (sangat tinggi). Analisis deskriptif mendapati bahawa kedua-dua pemboleh ubah mencatatkan tahap yang tinggi. Pengurusan disiplin sekolah mencatatkan nilai min iaitu 4.09 dan sisihan piawaian 0.62 , manakala kualiti kehidupan murid merekodkan nilai min sebanyak 3.94 dan sisihan piawai iaitu 0.70 . Secara rumusannya, murid-murid tingkatan empat di negeri Perlis, Kedah dan Pulau Pinang mengakui bahawa pengurusan disiplin di sekolah mereka adalah sangat cemerlang dalam menyusun atur, mengorganisasikan dan melaksanakan peraturan-peraturan sedia ada. Di samping itu, murid-murid juga mengakui bahawa kualiti kehidupan mereka di sekolah adalah sangat baik di mana mereka mempamerkan kegirangan dan keseronokan ketika berada di persekitaran tersebut. Jadual 2 berikut menunjukkan tahap-tahap bagi setiap pemboleh ubah kajian.

Jadual 2: Tahap pemboleh ubah kajian

\begin{tabular}{lcccc}
\hline Pemboleh Ubah & N & Min & Sisihan Piawai & Tahap \\
\hline Pengurusan Disiplin Sekolah & 539 & 4.09 & 0.62 & Tinggi \\
Kualiti Kehidupan Murid & 539 & 3.94 & 0.70 & Tinggi \\
\hline
\end{tabular}

\section{Hubungan Di Antara Pengurusan Disiplin Sekolah Dan Kualiti Kehidupan Murid}

Berdasarkan analisis korelasi Pearson, keputusan mendapati terhadap hubungan positif yang sederhana di antara pemboleh ubah pengurusan disiplin sekolah dan kualiti kehidupan murid, dengan nilai adalah $r$ $=0.450$. Nilai korelasi ini merujuk kepada indeks darjah hubungan sebagaimana yang dicadangkan oleh Fauzi et al. (2014) di mana sesuatu hubungan yang sederhana adalah di antara 0.40-0.59. Dapatan ini menggambarkan bahawa sesuatu pengurusan disiplin sekolah yang mantap mampu meningkatkan kualiti kehidupan murid walaupun berkadar langsung secara sederhana. Oleh itu, rumusan hubungan kedua-dua pemboleh ubah ini dipaparkan sebagaimana Jadual 3 berikut.

Jadual 3: Hubungan antara pengurusan disiplin sekolah dan kualiti kehidupan murid.

\begin{tabular}{|c|c|c|c|}
\hline Pemboleh Ubah & & $\begin{array}{c}\text { Pengurusan Disiplin } \\
\text { Sekolah }\end{array}$ & $\begin{array}{c}\text { Kualiti Kehidupan } \\
\text { Murid }\end{array}$ \\
\hline Pengurusan Disiplin & Korelasi Pearson & 1 & $0.450 * *$ \\
\hline \multirow[t]{2}{*}{ Sekolah } & Sigifikan & & 0.000 \\
\hline & $\mathrm{N}$ & 539 & 539 \\
\hline Kualiti Kehidupan & Korelasi Pearson & $0.450 * *$ & 1 \\
\hline \multirow[t]{2}{*}{ Murid } & Sigifikan & 0.000 & \\
\hline & $\mathrm{N}$ & 539 & 539 \\
\hline
\end{tabular}

\section{Perbincangan}

\section{Tahap Pengurusan Disiplin Sekolah}

Hasil kajian mendapati pengurusan disiplin sekolah berada pada tahap yang tinggi. Dapatan ini selari dengan kajian Wang dan Degol (2014) serta Lau, Wong dan Dudovitz (2018), di mana pengurusan 
disiplin sekolah yang cemerlang akan membawa kepada persekitaran yang selamat. Murid akan berasakan sekolah adalah lokasi yang selamat untuk dikunjungi disebabkan oleh faktor-faktor keselamatan yang tinggi. Murid juga tidak akan berasa bimbang sekiranya berlakunya kes-kes salah laku di sekolah seperti buli ataupun peras ugut. Hal ini kerana mereka berasa dilindungi oleh peraturanperaturan yang diwujudkan khas untuk membela pemangsa (Nurul Huda, Samsiah, Mohammad Nasir, \& Mohd Norakmar, 2020). Bagi murid yang melakukan kesalahan, sudah pasti mereka akan dikenakan hukuman yang setimpal dengan tingkah laku yang dipamerkan.

Dalam kebanyakan kes salah laku, peranan ibu bapa turut penting bagi memastikan sistem pengurusan disiplin sekolah berjalan dengan lancar. Sebagai contoh, kajian Brookmeyer et al. (2006) di Amerika Syarikat mendapati fungsi ibu bapa sangat bermakna dalam membantu pihak sekolah mengatasi masalah salah laku keganasan seperti bergaduh dalam persekitaran sekolah. Biasanya murid sukar untuk memberitahu guru tentang apa-apa yang berlaku di sekolah selain meluahkan perasaan tersebut kepada ibu bapa. Dengan cara ini, ibu bapa memainkan peranan untuk memberitahu pihak sekolah supaya menyiasat dan mengambil tindakan yang sewajarnya terhadap murid yang melakukan salah laku tersebut. Oleh itu, Menesini dan Salmivalli (2017) mencadangkan pihak pengurusan disiplin sekolah harus bertindak segera dalam membanteras setiap tingkah laku murid dengan secepat mungkin supaya hal ini tidak lebih parah pada masa akan datang.

\section{Tahap Kualiti Kehidupan Murid}

Dapatan kajian menunjukkan kualiti kehidupan murid adalah pada tahap yang tinggi. Keputusan ini telah menyokong dapatan sebelumnya oleh Huang, Wang, Tang, Chen dan Yu (2017) serta Varela, Guzman, Alfaro dan Reyes (2019). Kajian mereka mendapati kehidupan murid yang berkualiti adalah disebabkan oleh persekitaran yang positif sehingga menjana keseronokan dalam kehidupan seharian. Murid merasakan suasana yang sangat sejahtera apabila mereka dapat hidup tanpa ada rasa gangguan, tertekan dan melaksanakan sesuatu tanpa halangan. Dengan itu, murid boleh bebas untuk bergerak, menjalani kehidupan dengan normal dan tidak perlu bimbang dengan segala ancaman.

Tahap kualiti kehidupan murid ini sangat penting kerana jika tidak dititikberatkan akan mengundang rasa resah, gelisah dan sehingga menyebabkan kekecewaan yang panjang. Sekiranya tidak kawal dengan rapi, kemungkinan besar perkara-perkara negatif akan mudah menyerap masuk ke dalam diri murid sehingga mereka terdesak untuk melakukan perbuatan yang di luar kawalan kebiasaan (Payakachat, Gubbins, Ragland, Flowers, Stowe, 2014). Hal ini sangat membimbangkan seandainya murid mempamerkan tingkah laku yang negatif seperti buli, merokok, keganasan dan sehingga boleh mengakibatkan kes pembunuhan (Nor Asikhin, Nor Shafrin, \& Mohd Norakmar, 2020). Oleh sebab itu, tahap kualiti kehidupan murid mesti dijaga dengan baik dalam semua aspek supaya murid berasa lebih gembira ketika berada di rumah ataupun di kawasan sekolah. Sungguhnya, murid yang mempunyai kualiti kehidupan yang tinggi akan mempamerkan tingkah laku yang baik dan tidak akan mencetuskan masalah kehidupan seharian.

\section{Hubungan Pengurusan Disiplin Sekolah dan Kualiti Kehidupan Murid}

Analisis menunjukkan bahawa terdapatnya hubungan yang sederhana antara pengurusan disiplin sekolah dan kualiti kehidupan murid. Situasi ini adalah selari dengan kajian Mischel dan Kitsantas (2020) yang mendapati sistem pengurusan disiplin sekolah yang mantap berupaya untuk menyumbang kepada kualiti kehidupan sesuatu murid. Kajian mereka turut membuktikan kadar buli dalam kalangan murid semakin berkurangan apabila sistem pengurusan disiplin sekolah dikawal selia dengan baik. Hal ini termasuklah menguatkuasakan undang-undang dan peraturan yang diolah mengikut situasi dan keperluan semasa. Di samping itu, keputusan kajian ini turut menyokong dapatan Dorio, Clark, Demaray dan Doll (2020) yang turut mengakui kecemerlangan pengurusan disiplin sekolah yang sistematik dan teratur akan menjamin kepada kesejahteraan dan kualiti kehidupan murid seharian. Walau bagaimanapun, dapatan mereka mendapati kesejahteraan murid perempuan lebih tinggi sekiranya sistem pengurusan disiplin sekolah ditadbir dengan baik. Hal ini berkaitan dengan ciri-ciri keselamatan yang lebih berat kepada pengawasan murid perempuan yang diketahui bersikap lemah lembut dan senang untuk dipengaruhi oleh anasir-anasir negatif. 
Oleh sebab itu, pihak pentadbiran harus cakna dengan situasi yang berlaku terhadap perkembangan isu masa kini. Pengetua atau guru besar seharusnya mempergiatkan lagi usaha dalam memperkasakan sistem pengurusan disiplin sekolah ke tahap yang lebih cemerlang. Dalam hal ini, kajian Acosta et al. (2018) mendapati pihak pengurusan sekolah memainkan peranan besar bagi mempertingkatkan kualiti kehidupan murid ke tahap yang terbaik. Caranya adalah dengan menguatkuasakan peraturan sekolah selaras dengan isu-isu terkini dan melaksanakannya mengikut undang-undang yang ditetapkan. Kajian Bosworth, Garcia, Judkins dan Saliba (2018) turut bersetuju bahawa pengurusan disiplin yang teratur boleh mengurangkan kadar buli dan tekanan emosi murid di sekolah. Dalam erti kata yang lain, kebijaksanaan pengurusan displin sekolah dalam mengurangkan kes-kes salah laku murid akan meningkatkan kualiti kehidupan murid secara menyeluruh.

\section{Kesimpulan}

Pengurusan disiplin sekolah adalah satu jawatankuasa yang mengelola, mengawal dan melaksanakan fungsi-fungsi berkaitan dengan salah laku murid di kawasan sekolah. Jawatankuasa ini dibentuk bagi memastikan keselamatan dan kebajikan murid terus diberikan keutamaan terutamanya dalam menjalani kehidupan seharian di sekolah. Peranan pengurusan disiplin sekolah sangat luas merangkumi hal-hal berkaitan dengan pembentukan, penguatkuasaan dan pelaksanaan peraturan mengikut undang-undang semasa. Perkara ini tidak boleh diambil mudah kerana ia akan menghadirkan kesan yang sangat buruk sekiranya sesuatu tindakan yang dilaksanakan melanggar undang-undang. Oleh itu, pihak pentadbiran sekolah sepatutnya menunjukkan kewibawaan yang tinggi dalam memastikan setiap hukuman yang dikenakan terhadap murid adalah bersesuaian dan sepadan dengan kesalahan yang dilakukan.

Dalam masa yang sama, murid memerlukan kesejahteraan hidup ketika berada di kawasan sekolah. Murid akan rasa seronok, gembira dan teruja untuk hadir ke sekolah seandainya mereka berasa sangat selamat. Perasaan bimbang, takut dan kegusaran sepatutnya dihakis oleh setiap murid apabila berada di kawasan sekolah. Fenomena ini bermaksud murid tersebut dianggap telah mencapai suatu tahap kualiti kehidupan yang sangat baik. Bagi memastikan tahap kualiti kehidupan murid sentiasa tinggi, maka pihak sekolah melalui pengurusan disiplin harus memainkan peranan supaya memastikan persekitaran sekolah adalah tempat paling selamat untuk dikunjungi dan mewujudkan perspektif penilaian murid terhadap pengurusan disiplin murid secara positif. Permasalahan seperti buli, peras ugut, ponteng sekolah mahupun keganasan harus dibanteras dengan sebaiknya. Seandainya pihak sekolah dapat mengatasi masalah ini, maka murid akan rasa seronok, berpuas hati dan gembira untuk mengharungi sesi persekolahan tanpa ada rasa bimbang, takut dan kegusaran dalam diri.

\section{Rujukan}

Acosta, J., Chinman, M., Ebener, P., Malone, P. S., Phillips, A., \& Wilks, A. (2018). Evaluation of a whole-school change intervention: Findings from a two-year cluster-randomized trial of the restorative practice's intervention. Journal of Youth and Adolescence, 48(5), 876-890.

Anyon, Y., Gregory, A., Stone, S., Farrar, J., Jenson, J. M., McQueen, J., ... \& Simmons, J. (2016). Restorative interventions and school discipline sanctions in a large urban school district. American Educational Research Journal, 53(6), 1663-1697.

Atunde, M. O., \& Aliyu, T. T. (2019). Prevalence, causes and management of indiscipline in public secondary schools: Ilorin Metropolis in focus. Journal of Sociology, 3(3), 85-94.

Bosworth, K., Garcia, R., Judkins, M., \& Saliba, M. (2018). The impact of leadership involvement in enhancing high school climate and reducing bullying: An exploratory study. Journal of school violence, 17(3), 354-366.

Brookmeyer, K. A., Fanti, K. A., \& Henrich, C. C. (2006). Schools, parents, and youth violence: A multilevel, ecological analysis. Journal of clinical child and adolescent psychology, 35(4), 504514.

Creswell, J. W. (2018). Research design: Qualitative, quantitative, and mixed methods approaches (5th ed.). Thousand Oaks, California: SAGE Publications, Inc. 
Dorio, N. B., Clark, K. N., Demaray, M. K., \& Doll, E. M. (2020). School climate counts: A longitudinal analysis of school climate and middle school bullying behaviors. International Journal of Bullying Prevention, 2(4), 292-308.

Fauzi Hussin, Jamal Ali, \& Mohd Saifoul Zamzuri Noor. (2014). Kaedah penyelidikan \& analisis data SPSS. UUM Sintok, Kedah: UUM Press.

Gage, N. A., Larson, A., Sugai, G., \& Chafouleas, S. M. (2016). Student perceptions of school climate as predictors of office discipline referrals. American Educational Research Journal, 53(3), 492515.

Ghazali Darusalam, \& Sufean Hussin. (2018). Metodologi penyelidikan dalam pendidikan: Amalan dan analisis kajian (2nd ed.). Kuala Lumpur: Penerbitan Universiti Malaya.

Gregory, A., Clawson, K., Davis, A., \& Gerewitz, J. (2016). The promise of restorative practices to transform teacher-student relationships and achieve equity in school discipline. Journal of Educational and Psychological Consultation, 26(4), 325-353.

Huang, C. H., Wang, T. F., Tang, F. I., Chen, I. J., \& Yu, S. (2017). Development and validation of a quality of life scale for elementary school students. International journal of clinical and health psychology, 17(2), 180-191.

Jinot, B. L. (2018). The causes of a lack of discipline among secondary school learners in Mauritius. Mediterranean Journal of Social Sciences, 9(1), 35-46.

Kalaichalvi Patchaippan (2012). Pengurusan disiplin pelajar di sekolah menengah daerah Kulaijaya, Johor. (Tesis doktor falsafah). Johor Bahru: Universiti Teknologi Malaysia.

Lam Lee Mein (2013). Pengurusan disiplin di tiga buah sekolah menengah daerah Kota Tinggi, Johor. (Tesis doktor falsafah). Johor Bahru: Universiti Teknologi Malaysia.

Lau, C., Wong, M., \& Dudovitz, R. (2018). School disciplinary style and adolescent health. Journal of Adolescent Health, 62(2), 136-142.

Lawa, S. E., Wiyono, B. B., \& Supriyanto, A. (2019). Disciplining culture management of middle school students in the Eastern of Indonesia. Jurnal Pendidikan Humaniora, 7(3), 117-123.

Mancini, J. A. (2017). Student discipline strategies: Practitioner perspectives (Tesis doktor falsafah). Florida, USA: Nova Southeastern University.

Menesini, E., \& Salmivalli, C. (2017). Bullying in schools: The state of knowledge and effective interventions. Psychology, health \& medicine, 22(sup1), 240-253.

Mihanovic, Z., Batinic, A. B., \& Pavicic, J. (2016). The link between students' satisfaction with faculty, overall students' satisfaction with student life and student performances. Review of Innovation and Competitiveness, 2(1), 37-60.

Mischel, J., \& Kitsantas, A. (2020). Middle school students' perceptions of school climate, bullying prevalence, and social support and coping. Social Psychology of Education, 23(1), 51-72

Mitreva, E., \& Tushi, B. (2019). The quality of student life in the Republic of North Macedonia. ILIRIA International Review, 9(2), 99-118.

Mohd Faizal A. Ghani, Norfariza Mohd Radzi, Simin Ghavifekr, Husaina Banu Kenayatullah, \& Mokhtar Muhamad. (2014). Pengurusan disiplin murid di sekolah bandar dan luar bandar: Perspektif pemimpin sekolah. Jurnal Kepimpinan Pendidikan, 1(1), 7-40.

Mohd Ismail Othman. (2006). Menangani disiplin di sekolah. Kuala Lumpur: Utusan Publications \& Distributors. Sdn. Bhd.

Moloi, O. C. (2003). Student discipline strategies. Albany: State University of New York Press.

Nor Asikhin Ishak, Nor Shafrin Ahmad, \& Mohd Norakmar Omar. (2020). Issues and trends of depression among students in Malaysia. Universal Journal of Educational Research, 8(11B), 59515957.

Nurul Huda Ishak, Samsiah Mohd Jais, Mohammad Nasir Bistamam, \& Mohd Norakmar Omar. (2020). The validity and reliability of TF-CBTGC module for victims of bullying in schools. International Journal of Education, Psychology and Counselling, 5(37), 350-363.

Nyaga, B. N. (2018). The influence of students' council leadership training on discipline management in secondary schools in Kirinyaga-East Sub-County Kenya (Tesis doktor falsafah). Nairobi, Kenya: Pan Afrika Christian University.

Offem, O. O., Arop, F. O., \& Owan, V. J. (2019). Students' perception towards management of discipline and their academic performance in Cross River state. Global Journal of Academic Research (GJAR), 3(1), 34-40. 
Omemu, F. (2017). Relationship between principals administrative strategies and student disciplinary problems in secondary school, Bayelsa State. Journal of Education and Practice, 8(5), 100-104.

Payakachat, N., Gubbins, P. O., Ragland, D., Flowers, S. K., \& Stowe, C. D. (2014). Factors associated with health-related quality of life of student pharmacists. American Journal of Pharmaceutical Education, 78(1), 1-7.

Phuntsho, S. (2021). Discipline management in urban middle secondary schools: Principals, counselors, students and parents perceptions. Journal of Education, Society and Behavioral Science, 34(2), 1119.

Quinn, D. J. (2017). School discipline disparities: Lessons and suggestions. Mid-Western Educational Researcher, 29(3), 291-298.

Raskaukas, J., \& Modell, S. (2011). Modifying anti-bullying programs to include students with disabilities. Journal of Teaching Exceptional Children, 44(1), 60-67.

Sekaran, U., \& Bougie, R. (2016). Research methods for business: A skill building approach (7th ed.). West Sussex, United Kingdom: John Wiley \& Sons Ltd.

Steger, M. F., Frazier, P., Oishi, S., \& Kaler, M. (2006). The meaning in life questionnaire: Assessing the presence of and search for meaning in life. Journal of Counselling Psychology, 53(1), 80-89.

Syahril, S., \& Hadiyanto, H. (2018). Improving school climate for better quality educational management. Journal of Educational and Learning Studies, 1(1), 16-22.

Varela, J. J., Guzman, J., Alfaro, J., \& Reyes, F. (2019). Bullying, cyberbullying, student life satisfaction and the community of Chilean adolescents. Applied Research in Quality of Life, 14(3), 705-720.

Wang, M. T., \& Degol, J. (2014). Staying engaged: Knowledge and research needs in student engagement. Child development perspectives, 8(3), 137-143. 